\title{
Practical appraisal to ethics in fetal death: a case of anasarca
}

\author{
M. Menegaki ${ }^{1}$, P. Pavlidis ${ }^{2}$, D. Tamiolakis ${ }^{3}$
}

\section{Summary}

Human response to the death of a loved one varies among different societies, religions, cultures, and races through a series of ceremonies and observances. Since postmortem examination may be offensive to some of these groups, the determination of the need for autopsy should be based on ethical as well as legal principles. Ethics is the "science which treats of human nature and the grounds of moral obligation; the science of human duty". Although it is the responsibility of society and the duty of a medical examiner/coroner to provide medicolegal death investigation, establishing dogmatic policy is apt to create confrontation rather than fulfillment of statutory obligations. The approach to an objection to autopsy should stress values of "respect, compassion, kindness and courtesy beyond the minimum required by any policy or guideline".

Key words: Ethics. Fetal death.

Oncología, 2006; 29 (2):81-84

\section{Resumen}

La respuesta humana hacia la muerte de un ser querido difiere en las distintas sociedades, religiones, culturas y razas, y se pone de manifiesto en una serie de ceremonias y observancias. Dado que el examen post-mortem puede resultar ofensivo para algunos grupos, la determinación de la necesidad de una autopsia se debe basar tanto en la ética como en los principios legales. La ética es "la ciencia que trata de la naturaleza humana y de los fundamentos de las obligaciones morales; la ciencia de los deberes humanos" Aunque es responsabilidad de la sociedad y deber del examinador médico o del juez de instrucción solicitar la investigación de la muerte desde el punto de vista médico-legal, el establecimiento de una política dogmática tiende a crear confrontaciones en lugar de cumplir las obligaciones estatutarias. El enfoque de objeción a una autopsia debe hacer hincapié en los valores de "respeto, compasión, amabilidad y cortesía por encima del mínimo requerido por cualquier política o directriz".

Palabras clave: Ética. Muerte fetal.

\footnotetext{
${ }^{1}$ Department of Histology - Embryology, Democritus University of Thrace,

${ }^{2}$ Department of Legal Medicine, Komotini,

${ }^{3}$ Department of Cytology, General Hospital of Chania, Crete, Greece.
} 


\section{Introduction}

An ethical dilemma for the death certifier is statutory authority versus family autonomy, which necessitates a balance between societal implications of the death investigation and respect for the family's wishes ${ }^{1}$. The problems consist of satisfying legal requirements in the public interest and the avoidance of needless publicity, litigation, and legislative reactions. Controversy over the autopsy wastes valuable personnel time and effort, which could paralyze a busy day at the office. In addition, it is conceivable that a family might later claim that a medical examiner had a duty to perform an autopsy despite family objection and bring suit on the basis that the family lacked ability to make a sound judgment decision in the matter ${ }^{2}$.

The purpose of this paper is to explore some of the implications for this balanced approach to the ethics of fetal death ${ }^{3}$. We do so in terms of the concept of the fetus as a patient, which has become a central concept in obstetric ethics internationally.

The concept of the fetus as a patient is not usefully understood in terms of the independent moral status of the fetus-that is, some features of the fetus that, independent of other entities, including the pregnant woman, physicians, and the state, generate the obligations of others. This is because all attempts to establish such independent moral status are doomed to failure. Put simply, there are irreconcilable differences among philosophic and theologic methods that have been deployed over the centuries of debate about the independent moral status of the fetus ${ }^{4}$.

A more fruitful line of argument is that the moral status of the fetus depends on whether it is reliably expected later to archive the relatively unambiguous moral status of becoming a child and, later, the more unambiguous moral status of being a person. The fetus is a patient when reliable links exist between it and its later archiving the moral status as a child and then a person ${ }^{4}$.

The first link between a fetus and its later achieving moral status as a child and then a person is being presented to a physician and viability, the ability of the fetus to exist ex utero. This requires levels of technologic support necessary to supplant immature or impaired anatomy and physiology through the neonatal period and into the second year of life, times at which no one disputes that childhood and then adulthood exist. Viability is, therefore, not an intrinsic characteristic of fetus, but a function of both biology and technology. In developed countries, fetal viability occurs at approximately the $24^{\text {th }}$ week of gestational age, as determined by competent and reliable ultrasound dating ${ }^{5}$.

The second link between a fetus and its later achieving moral status as a child and then a person is being presented to a physician and the decision of the pregnant woman to continue a previable pregnancy to viability and, subsequently, to term. This is because a previable fetus and its later achieving moral status as a child and then a person is the pregnant woman's autonomy, exercised in the decision not to terminate her pregnancy and to present the fetus (and herself) to the physician, because technologic factors do not exist that can sustain the fetus ex utero.

In summary, the viable fetus, when the pregnant woman presents herself for a medical care, is a patient. The previable fetus is a patient solely as a function if the pregnant woman's decision to confer the status on the fetus and present herself for care. When the fetus is a patient, the physician has beneficence-based obligations to protect its life and health ${ }^{4}$. These obligations must be considered along with beneficence-based and autonomy-based obligations to the pregnant woman.

The concept of the fetus as a patient can be used to develop a balanced approach to the ethics of fetal research-that is, an approach that protects the vulnerable fetus, but maintains access of pregnant women to clinical research that might significantly benefit the fetus. The proposed fetal intervention is reliably expected (usually on the basis of previous animal studies) either to be life-saving or to prevent serious and irreversible disease, injury, or handicap for the fetus. Among possible alternative designs, the intervention is designed in a way that involves the least risk of mortality and morbidity to the fetus. The mortality risk to the pregnant woman is low, and the risk of diseases, injury, or handicap to the pregnant woman is low or manageable.

The mission of medicolegal death investigation is to provide society with an accurate data base to judge how and why people die. Statutory laws are developed with the concordance of populations to promote this endeavor. The procedure by which one proce- 
eds must be ethical and not stranded in unchangeable policies. Concern, respect, politeness, and appropriate judgement tends to disperse anxiety and temper objections. Dogmatism sets the stage for confrontation and misinterpretation of the purpose of the medical examiner/coroner. Such action eventually leads towards inhibitory litigation or legislation.

Herein we report a case-example of fetal death due to handicap for the fetus.

\section{Case report}

A male fetus of $21 \mathrm{~cm}$ crown-rump (CR) length, $29 \mathrm{~cm}$ crown-heel $(\mathrm{CH})$ length and $750 \mathrm{gr}$ weight was admitted for autopsy. On opening the thorax and on the cut surfaces of the right lung, multiple small cysts measured less than $0,2 \mathrm{~cm}$ in greatest dimension, were found. The cysts occupied the entire right lung. The microscopic appearance was suggestive of immature lung with a predominant background of alveoli-like structures lined by cuboidal cells, presumably alveolar epithelial cells type II (Fig. 1). Occasional randomly scattered irregular thin-walled bronchiole-like structures were interspersed between the alveoli-like zones. The histological appearance was similar to that of the proximal acinus with terminal bronchiole-like structures and structures resembling alveoli (Fig. 2). There were occasional striated muscle fibers in the wall of the cysts but no cartilage was found.

Findings were consistent with type 3 variant of congenital cystic adenomatoid malformation (CCAM) of the lungs. The cause of fetal death was hydrops (anasarca).

The evidentiary purpose of this mandated autopsy was discussed with the family, who eventually understood the purpose of postmortem examination. A compromise consisted of a visceral in situ examination with detailed documentation.

\section{Discussion}

In the United States, federal regulations govern fetal research and are known as 45 CFR 46 or the (Common Rule). All public and private institutions receiving federal funding for clinical research must abide by these regulations. (No pregnant woman

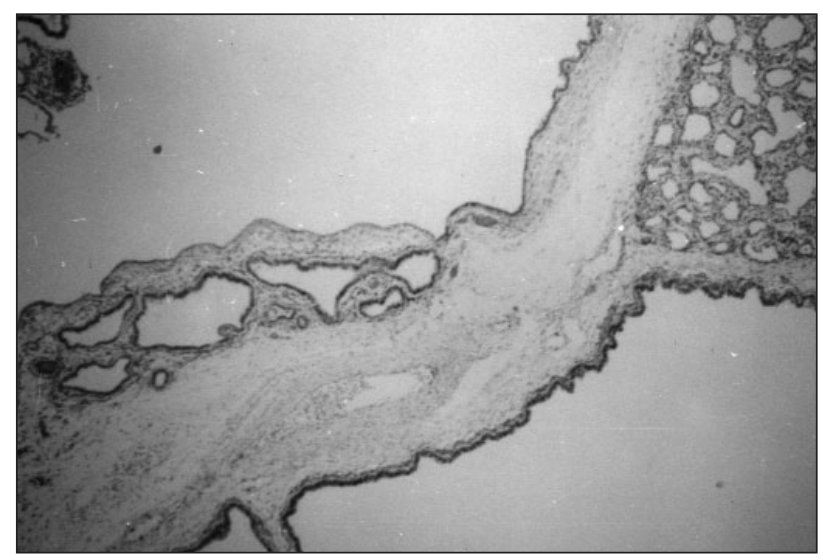

Fig. 1 Histologic appearance of CCAM. On the upper right, cleft-like spaces lined by cuboidal epithelium.

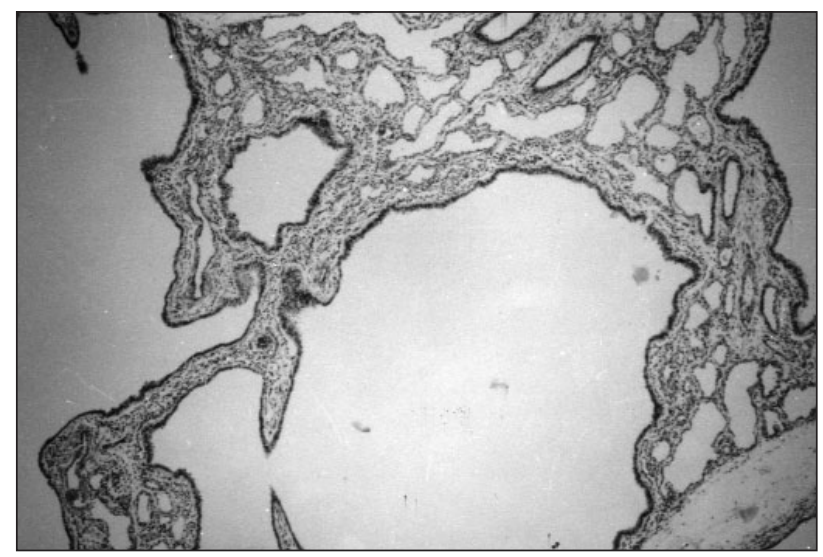

Fig. 2 CCAM. Low-power view showing small and large cysts lined by cuboidal cells.

may be involved as a subject in an activity covered by this subpart unless: 1) The purpose of the activity is to meet the health needs of the mother, and the fetus will be placed at risk only to the minimum extent necessary to meet such needs; or 2) The risk to the fetus is minimal ${ }^{6}$.

The protective approach to research involving pregnant women reflected in this regulatory language has recently been criticized for being overprotective. This criticism, which has wide-reaching implications for the ethics of human-subject research in all countries, has been made a part of a broader critique of an ethics of human-subject research based almost exclusively on informed consent and protecting vulnerable subjects of research (potential subjects who have diminished capacity to provide informed consent and are, therefore, at risk for exploitation). This critique instigates the argument that the 
exclusive concern with informed consent-which makes very good sense given the history of abuse of human subjects of research in the United States and in the horrific Nazi medical war crimes earlier-has led to the exclusion of populations of patients from clinical research. As a result, these populations can be denied the benefits of research ${ }^{7}$. For example, it is well known among advocates of women's health that one disturbing outcome of this exclusion of women of childbearing years is that results of studies done exclusively on men must be extrapolated to the clinical care of women ${ }^{8}$. This is obviously not an adequate standard for women's health, especially in developed countries that can afford the cost of clinical research.

Instead of a protective approach, based on the sole ethical consideration of informed consent, a more balanced approach has been recommended. Brody ${ }^{9}$ has recently summarized this emerging, new approach to the ethics of human-subject research. (We are in the midst of a reconceptualization of justice in research, The older conceptualization, the protective conceptualization, emphasized the protection of vulnerable subjects from being used without their consent and from being exploited in excessively risky research. The newer conceptualization, the balancing conception, incorporates access to the benefits of research as an additional demand of justice. As a result, justice in research is now seen as demanding a proper balance of access to the benefits of research with protection from unconsented use and from exploitation). The balanced approach is population-based, whereas the protective approach focuses on individuals.

\section{Conclusions}

Fetal research, raises ethical challenges for clinical investigations in maternal-fetal medicine. We have argued for the concept of the fetus as a patient as the conceptual and clinical basis for addressing these ethical challenges regarding the design, conduct, and regulation of fetal research.

\section{References}

1. Ethical Advisory Committee Report, Florida Department of Law Enforcement, Medical Examiners Commission, Lallahassee, FL, 1987.

2. Hirsch CS. (Talking to the family after an Autopsy), Archives of Pathology and Laboratory Medicine, Vol 108, June 1984, pp.513-514.

3. Chervenak FA, McCullough LB. Ethical dimensions of fetal research. J Obstet Gynaecol Res 2002,28:3-7.

4. McCullough LB, Chervenak FA. Ethics in Obstetrics and Gynecology. New York: Oxford University Press: 1994.

5. Chervenak FA, McCullough LB. The limits of viability. J Perinatol Med 1997,25:418-420.

6. Department of Health and Human Services. Regulations for the protection of human subjects. 45CFR 46.207.

7. Kahn JP, Mastroiani AC, Sugarman J, eds. Beyond Consent: Seeking Justice in Research. New York: Oxford University Press: 1998.

8. Kass N. Gender in Research. In Beyond Consent: Seeking Justice in Research. Edited by Kahn JP, Mastroiani AC, Sugarman J. New York: Oxford University Press: 1998:67-68.

9. Brody BA. Research on the vulnerable sick. In Beyond Consent: Seeking Justice in Research. Edited by Kahn JP, Mastroiani AC, Sugarman J. New York: Oxford University Press: 1998:32-46.

\author{
Correspondence to: \\ D. Tamiolakis \\ Department of Cytology \\ General Hospital of Chania \\ Crete, Greece. \\ cyto@chaniahospital.gr
}

